\title{
“I feel Danish but...": a case study on national identity formation and ambivalence
}

\author{
L. Koefoed and K. Simonsen \\ Department of Environmental, Social and Spatial Change, Roskilde University, Denmark \\ Correspondence to: L. Koefoed (lmartin@ruc.dk) and K. Simonsen (kis@ ruc.dk)
}

Received: 31 July 2012 - Revised: 21 November 2012 - Accepted: 6 December 2012 - Published: 7 October 2013

\begin{abstract}
Non-western minorities in Europe, one can argue, are experiencing particularly vulnerable processes of subjectification and identification. They are often caught between double processes of inclusion/exclusion, integration/segregation or identification/estrangement. This article explores some of the complex and ambiguous processes of identification within this group, in connection with development of the spatial identity of Danishness. It starts with a short theoretical pinning down of the figure of "the stranger" working as a basis for the empirical analysis. Organised in three sections, each interpreting a specific narrative of identification, the analysis subsequently explores processes and problems of identity formation within a minority group increasingly designated as "strangers" within the Danish nation state. The article concludes on the different ways in which uncertainty and ambivalence infiltrate the identity formation.
\end{abstract}

\section{Danishness and ambivalence}

\section{Introduction: the figure of the stranger}

Thinking about subjectivities in crisis in a European context, it can be argued, some of the most vulnerable identity formations occur amongst newcomers to the region continuously facing identification as "strangers". In this article we will explore the identity formation in this situation of "strange(r)ness" through a case study from Denmark, but first we will take a short look at the very concept of the stranger. ${ }^{1}$

In popular culture the stranger often appears as a pregiven and naturalised figure, but the starting point for our use of the term is (on the contrary) that nobody simply is a stranger. Rather, everybody is continuously constituted in everyday encounters in a continuum of positions between familiarity and strange(r)ness, and between "here" and "there". Strange(r)ness, then, is basically a spatial relation, and the stranger is a relational figure or an interaction constituted

${ }^{1}$ Due to the research object our interest here focus on specific others, encountered with surprise or even fear, more than the phenomenological generalised other found in authors as MerleauPonty, Levinas and Derrida. in bodily encounters - face-to-face and/or mediated through images formed in encounters performed in other times and other spaces. Such an understanding can already be read out of classic texts on the figure; for example when Simmel (1950) states that the stranger is a person "who comes today and stays tomorrow", or when Schuetz (1944), along the same line, understands the stranger as always being in a situation of approaching - coming closer to those who are at home. The stranger is a figure living within the spatial ambivalence of proximity and distance. Listen again to Simmel: "In relationship to him, distance means that he, who is close by, is far, and strangeness means that he, who also is far, is actually near" (1950:402). The relationship of the stranger to the place of residence is simultaneously one of attachment and detachment (or we could add of inclusion and exclusion). $\mathrm{He} / \mathrm{she}$ is inside and outside at the same time.

Recently, this relational understanding is developed by Ahmed (2000). She challenges the assumption that the stranger is simply anybody whom we do not know. Rather $\mathrm{s} / \mathrm{he}$ is "some-body whom we have already recognised in the very moment in which they are 'seen' or 'faced' as a stranger" (2000:21). The figure of the stranger is "painfully familiar" in its very strange(r)ness. It has already come too close and been recognised as a body out-of-place: 
The stranger then is not simply the one that we have not yet encountered, but the one whom we have already encountered, or already faced. The stranger comes to be faced as a form of recognition: we recognise somebody as a stranger, rather than simply failing to recognise them (2000:21).

Hence the constitution of strangers involves emotionally charged spatial negotiations over mobility and home, (imagined) communities, boundaries and bridges etc. "Like bodies" and "unlike bodies" do not precede encounters of inclusion or expulsion. Rather, likeness and unlikeness as "characteristics" of bodies are produced through these encounters. Part of that process is the experience of being exposed to oppressive visions or emotions. Fanon (1967) describes the phenomenology of incorporating otherness and the development of a "double consciousness" due to the enculturation of the body. Men and women of colour, he says, develop a third-person consciousness trying to reconcile their own experiences with the operation of a "historical-racial schema" within which their corporeal schema is supposed to fit.

In this way, ambivalence gets into the centre of the identity formation of the "stranger" (see a.o. Bauman, 1991; Diken, 1998). Understanding ambivalence as "the possibility of assigning an object or an event to more than one category" (Bauman, 1991:1), the stranger becomes the prototypical example of ambivalence. Belonging to more than one category means ambivalence, contingency, and indeterminacy as long as the search for definitions based on either/or is the norm. Bauman relates to oppositions such as friend/enemy, good/evil, right/wrong, etc. and argues that if they are pressed upon the stranger, s/he will come out simultaneously underand overdetermined. The stranger rebels against such oppositions and belongs to the family of undecidables, those baffling unities that are neither/nor.

In the rest of this paper we will explore in three sections some of the processes and problems of identity formation experienced and performed among alleged "strangers" within the Danish nation state. The purpose is on the one hand to analyse the habitability of the nation state for ethnic minorities and on the other hand to show the complexity of the processes going on. But first we give a short presentation of the research project that forms the basis of this article.

\section{The analysis}

The background of the article is a research project titled The Stranger, the City and the Nation performed in the period 2007-2009 (see Koefoed and Simonsen, 2010). The empirical material of the project, which is exploited in this article, comes from in-depth interviews amongst Copenhagen residents having a Pakistani background. We chose this group for two reasons. First, with a history dating back to the 1960s, it is a well-established immigrant group in Denmark. Secondly, as Muslims, the group has increasingly experienced a signification as "strangers", in this way providing a case that accentuates the issue in question.

The analysis in this paper is structured in three sections each showing different dimensions of the ambivalence involved in the construction of a "Danish" identity. Also, it is to a large degree based on extracts from the empirical material. As such, it consists of a set of constructions achieved through the interpretation of the interviews together with theoretical considerations. In a paper of this length, extracts from the interviews will of course be shorter and even more selective than in the original analysis, thereby leaving the process of interpretation more impenetrable. Using extracts from interview transcripts in a text does not, of course, imply a claim of "authenticity" or "verificational realism" (Crang, 2002). The transcripts are texts produced in dialogue or "fusion of horizons" between interviewer and narrator, a joint project on giving meaning to the experiences and events unearthed by the narrator (Gadamer, 2004). However, the extracts do endow the presentation with some flavour of "flesh and blood" and establish a certain transparency of the interpretation.

\section{The narrative of decline}

Honestly, I have to admit that sometimes when I describe myself as an integrated part of the Danish society, I get cold feet. This ambivalent feeling regarding my identity has nothing to do with lack of self-confidence or lack of trust in the Danish society, it is recognition of the facts of Denmark today... A great part of Danish authorities and the Danish population have lately changed attitude from first being kind, later indifferent and finally outright hostile. Democratic values, sense of justice and equal rights are watered down when it is about people with another skin colour, religion or culture (Qurashi, 1999, p. 128/132, our translation).

Bashy Qurashi, an author of Pakistani origin, came to Denmark in the 1970s as a young man, and in the conversations we had with groups of men from the same generation, we met the same story, the same grief and the same anger as he expresses. One of them told how Danish employers in the 1970s advertised in Pakistani newspapers. They clearly wrote, he says, "Denmark needs workers. If you come here, you will get work, you will get accommodation, you will get training." (Kaleem, 62) In some sense he feels that he has come to Denmark on false assumptions: "If I thirty years ago have had the knowledge that I have today, I would never have come to Denmark!"

These men did arrive to the country young and hopeful, many of them did not expect to stay for more than a couple of years, but eventually they brought their families and now Denmark is their home. When they arrived, Denmark was "a paradise", some of them tell. Danish people were open 
and kind and there were jobs for everybody. Now, they have stayed nearly forty years. They think that they have done their duty; worked all the time, paid their taxes and helped to make Denmark a rich country. And suddenly they become "strangers" that many Danes want to get rid of: "Many people want us to get out of the country. But we have worked here in thirty-seven years and have paid our tax". The events of 9-11 have added to the bad experiences. They now feel that there are even suspicions thrown on them as terrorists. The narrative often refers to the political sphere, personified with the leader of the right-wing Danish people's party. The subject is lack of recognition of their efforts and contributions and a feeling of being excluded from the political process. For example, many refer to problems of becoming old in Denmark expressing a fear of becoming lonely and isolated because their needs are not included in the politics of senior citizens. This is what we call "the narrative of decline", told by many but in particular articulated by the "guest workers" living in Denmark since the 1970s. It expresses experiences of a gradual worsening of the attitude towards ethnic minorities, and it leaves these elderly people with feelings of grief, anger and insecurity about future for both themselves and their descendants.

\section{"A foot in both camps"}

You are split between two cultures ... you are somehow mixed and confused between all these values. (Shahda, 38)

One of the most common issues in literature on ethnic minorities in European cities/countries is about problems of self-identification and the introduction of concepts such as hybridity, syncretism, creolisation, third cultures or hyphenated identities. They all intend to describe how the work of making "home away from home" creates "homelessness" and ambivalence but also new ethnicities or mixed forms gaining their own worth and vitality (see among many others Hall, 1992; Gilroy, 1993, 2000; Back, 1996). Gilroy in this connection talks about "double consciousness", in this way placing himself close to both Fanon's "third-person consciousness" and Bauman's understanding of ambivalence and undecideability. The theories are contested and involve a doubleness that characterises the different versions to a different degree. On the one hand they describe a conflictual and painful process in the diaspora consisting of uprootings, regroundings and emotional work around the making of "home", as when Brah talks about home as "a mythic place of desire in the diaspora imagination (1996:192, see also Cohen, 2008 and Werbner, 2002). On the other hand they represent a more hopeful process involving creative play with cultural difference and re-mixing of dislocated cultures.

\subsection{To stick to one's roots}

My roots are in Pakistan but I am born and bred in Denmark. That means, I am caught in two cultures. For example, last week I came home from Pakistan where I had been staying for two weeks. And when I came back, I missed Pakistan - just like when I departed from here, I was sad to leave Denmark. It feels like sailing: you have to have both feet in the same ship, but you don't really know in what direction you are taken. It is difficult to handle being part of those two cultures. It is difficult in this way feeling both either/or and both/and, I think. (Shabbir, 29)

Shabbir is born in Denmark but is keen to stick to his Pakistani roots. He is rather split and ambivalent in his double affiliation. When he is in Pakistan, he misses Denmark, and when he is Denmark, he misses Pakistan. He uses the metaphor of the ship to illustrate how he is carried between two "cultures": "you don't really know in what direction you are taken". For him, the fluctuation between what he sees as two cultures leads to an indeterminacy, which can be difficult to handle. He is living a transnational or diaspora identity that obviously makes him feel uncomfortable. As Bauman suggested, belonging to more than one category for him means ambivalence and undecideability.

\subsection{Reflexive doubleness}

....and then there is Salman Rushdie's saying that "trees have roots, people have feet". I love that one. Because we are on a journey and the people we meet on our way, they are the ones that shape us. Both physically and mentally we are on a journey. So it is arbitrary to put on labels, because it still gives no meaning to say that I am Danish or that I am Pakistani. Because sometimes I am, sometimes I am not. Sometimes I am something completely different; sometimes I am a doctor, sometimes I am a lad playing table-football in a club. In this way it is our common features, that bind us together, and our differences that push us apart. (Ikram, 31)

Ikram reflects over the formation and practice of his identity. He uses the spatial travel metaphor as an illustration. Characteristic of the travel metaphor is that it defines a road (Lakoff and Johnson, 2002). So what Ikram says is that identity is not a bounded state but a road that we follow and a succession of spatial encounters that form us. Even if he by mentioning "common features" and "difference" in the end of the extract re-introduce boundary work. The travel metaphor also provides identity formation with a sequence or a temporality in accordance with theories seeing subjectivity and identity as continuous becoming. Ikram's reflections however also add 
something else - namely that all identity claims are situated: "sometimes I am, sometimes I am not. Sometimes I am something completely different". The identity claims put into work depend on the specific temporal and spatial context in which they are activated. Ikram's reflexive doubleness, then, moves beyond being a mixture towards becoming a challenge to the categories.

\subsection{Where do you come from?}

Many of the respondents say that they feel like a stranger when they visit Pakistan. Among them is Hanif who illustrates it with a little story from his childhood when he, arriving back to Denmark, laid down and kissed the ground - in this way bodily performing the feeling of coming home. He also says

Oddly enough I meet "where do you come from?" both here in Denmark, where they mean down there, and down there where they, when they ask "where do you come from?", mean Denmark. So in this way you are also split in two, if you can say so. (Hanif, 27)

In this way he illustrates how identity formation involves not only identification but also categorisation. Jenkins (1996, 2000) in this connection identifies two ways in which interaction between similarity and difference works - namely in what he calls "the internal and external moments of the dialectic of identification" (2000:7). They concern how we identify ourselves (internal self- or group identification), how others identify us (external social categorisation), and the ongoing interplay of these in processes of social identification. Therefore, the question of "a foot in both camps" can, as well as concerning a double affiliation, be a question of lacking recognition as a valid part of both categories. That is, besides being a question of both/and it can rather more be one of neither/nor.

\section{Danishness and recognition}

A repeated theme in the narrative material is the question of being recognised as a full member of the Danish community. Here we have found Axel Honneth's normative ideas about the need for recognition useful. To him, the struggle for recognition is connected to the suggestion that intersubjective recognition stands out as a necessary condition for intact identity formation (Honneth, 1995). Honneth identifies three differentiated spheres of mutual recognition. The first of these is the private sphere based on the recognition principle of emotional support or love. The second sphere is the legal sphere formed around the principle of cognitive respect or equal legal treatment. Finally, and very useful for the analysis, Honneth talks about what we could call a sphere of achievement opening up for the possibility of subjects to gain social esteem and to relate positively to their concrete traits and abilities. Recognition in this sphere is connected to the valuation of achievement within specific fields or communities. They can be cultural, political or work communities, and the recognition renders participants able to understand themselves as subjects whose abilities and ways of life are valuable for the common ethical goals of the community. Each of these different modes of recognitions also contains possible forms of moral disrespect. Moral resentment within communities for example emerges if members of the community are given the signal that their contribution to the community is not valued or, more generally, individual or collective ways of life are denigrated. Asked about his belonging to the Danish community Hanif says

Actually, it is one of the biggest and best questions which I - every day, from I wake up to I go to bed, I am in doubt. Sometimes I can say Of course, sometimes it becomes Never. Sometimes I think: No! So I will never be sure that I will be recognised as Danish. Because I feel 100 percent Danish. But if I go out and experience this discrimination, then it immediately pops up, this thing about that you are not Danish... Look at my album and tell me what the difference is except that we have a darker skin... We have also been in Legoland with the family. We have also been to the Zoo. We have pictures where we are wearing clap hats, Danish flags and Danish clothes. We went to an international football match with the parents. And in Legoland with feathers in our hair roasting twistbread on the fire. I mean, what in hell more do you want? (Hanif, 29)

Hanif expresses here the doubt and the ambivalence raised by the recurring question of being recognised as a full member of the Danish community. He describes how his emotions constantly alternate between "of course" and "never". The narrative illustrates a central theme in the narrative material the discrepancy between feeling Danish and not being recognised as a valid member of the imagined community. Although Hanif, as he explains, feels a hundred percent Danish, he finds himself in a constant struggle for recognition. In this case it is about recognition within the sphere of achievement that is supposed to open up for the possibility of subjects to gain social esteem. The respondent feels that he belongs but that he is denied the recognition from the Danish community mainly because of discrimination. The example here is about how boundaries are constructed through estrangement that for Hanif (and others) comes into conflict with his self-identification with the nation. In the extract he illustrates his Danishness through a "fictive" family album that gives voice to struggles and questions about what is needed to be recognised as a Dane. "What in hell more do you want?" is more than a rhetorical question. It gives voice to uncertainty and ambivalent feelings about the possibility of being fully recognised as a member of the imagined community. 


\subsection{Am I welcome?}

And I say to myself, I live in Denmark - for better or for worse. It is ok, I don't die from it. I always say: I love Denmark, it is my country. But now, I don't really know, because how long are we welcome, and will it be worse? I sometimes fear so. But I also say to myself that not everything is bad, for instance I have my neighbour on the other side. A lot of people are very nice, they really are. (Shahda, 38)

Many respondents express their uncertainty over their status in the imagined community in questions related to whether they can feel welcome. It is a identification with the nation that takes place between inclusion/exclusion and separation/connections. In this extract Shahda explains that the nation is a place where she feels she belongs ("I love Denmark, it is my country"). At the same time she expresses that her attachment to the nation is not without reservations. She articulates her doubt through the "small" and "banal" unnoticed word "but" ("but now, I don't really know..."). This doubt creates a double process of identification that in Shahda's case (in common with many other respondents) could be formulated as a general feeling: "I feel Danish but...." Shahda expresses a pragmatic approach to it: "I don't die from it", but it simultaneously gives rise to a more fundamental uncertainty that makes it difficult to identify completely with the nation. She constantly works with the estrangement by reminding herself that people are friendly when it comes to relations in everyday life.

\subsection{Media and debate}

Many of the respondents relate the feeling of ambivalence and uncertainty to the way they are constantly represented as "strangers" in the media and in public debate.

The image of us as minorities and the way we are looked upon are really awful and miserable. It hurts so much. Well I think it has been terrible with Pia Kjærsgaard (leader of the right wing Danish People's Party, red). She is vulgar, especially because of the words she uses. And I must say I cry. I've been so upset by it. I've stopped watching it. It is violence. It is violence against me as a person. Because she does not explain what she means when she says that we are a threat, that Islam is a threat, and Muslims are a threat... I get so angry because she attacks me and tells me that I also have a problem. That I am a problem because I have another skin colour and hair colour. And now even my daughter can feel it. She asks: "I am a Muslim, mum. Am I also a problem"? It is dangerous. It is terrible. (Safiya, 37)
This extract illustrates the significant feelings of being misrepresented and excluded from the Danish imagined community in discourses and in media representations. As the respondent explains, she feels "hurt" and offended by the continuing articulation of herself as being the problematic "other" represented as a threat to the Danish Community. Safiya constantly struggles with the way she is transformed and forced into a generalised category the "other" represented as the enemy of the nation. In this case the lack of recognition is strongly felt as violence. Thereby she points to the problem of symbolic violence and the way violence is embodied and performed in the language of nationalism (Zizek, 1993 and 2008). A dominant banal nationalism (Billig, 1995) that can bee related to the growth in national populism, right wing nationalism and racism in Denmark (Koefoed and Simonsen, 2007). In this case the daily misrepresentations of Muslims and Islam as being a threat to the society is experienced as a moral disrespect - a violent lack of recognition of Muslim minorities in Danish Society.

\section{Conclusions}

In this paper we have explored some of the processes and problems of identity formation experienced among designated "strangers" within the Danish nation. One conclusion is that the general experiences can be formulated in the statement "I feel Danish but..." The respondents cannot identify their belonging to the nation without this "but" that are related to the experiences of being (re) produced as a border figure of the nation - an internal stranger who constantly acts in the grey area between inclusion/exclusion. The ambivalent feelings are related to the question whether it is possible to become a full member of the Danish nation. The "but" is expressed with ambivalence in three different ways. First it is expressed in narratives of decline. These stories, especially expressed amongst "guest workers" who moved to Denmark in the 1970s, are about the experiences of a gradual worsening of the attitudes towards ethnic minorities. Secondly, in what we call a "foot in both camps", we find ambivalence related to transnational identity. The feeling of double consciousness experienced either as a split between two cultures or as a reflexive and situated practice of identity. Third, there is the crucial point about recognition - the discrepancy between feeling Danish and not feeling recognised as such by the surroundings. The problem of not being recognised as a valid member of the community is felt in daily life but not least in media discourses and public debate. The lack of recognition is experienced as symbolic violence and generates feelings of frustration, anger and sadness preventing full identification with the national space.

Acknowledgements. We thank participants in the session at International Critical Geography Conference in Frankfurt 2011 for a constructive discussion. 
Edited by: O. Söderström

Reviewed by: two anonymous referees

\section{References}

Ahmed, S.: Strange Encounters. Embodied Others in PostColoniality, London and New York, Routledge, 2000.

Back, L.: New Ethnicities and Urban Culture. Raciss and Multiculture in Young Lives, London, Macmillan, 1996.

Bauman, Z.: Modernity and Ambivalence, Ithaca/New York, Cornell University Press, 1991.

Billig, M.: Banal Nationalism. London, Thousands Oaks and New Delhi, Sage, 1995.

Brah, A.: Cartograhies of Diaspora. Contesting identities, London and New York, Routledge, 1996.

Cohen, R.: Global Diasporas: An introduction, Abingdon, Routledge, 2008.

Crang, M.: Qualitative Methods: the New Orthodoxy?, Prog. Hum. Geog., 26, 647-655, 2002.

Diken, B.: Strangers, Ambivalence and Social Theory, Aldershot, Ashgate, 1998.

Fanon, F.: Black Skin White Mask, New York, Grow Press, 1967.

Gadamer, H.-G.: Sandhed og metode. Grundtræk af en filosofisk hermeneutik, Århus: Systime Academic, 2004 [1986].

Gilroy, P.: The Black Atlantic: Modernity and Double Consciousness, Cambridge, Mass, Harvard University Press, 1993.

Gilroy, P.: Between Camps: Nations, Cultures and the Allure of Race, London and New York, Penguin, 2000.
Hall, S.: New Ethnicities, in: "Race", Culture and Difference, edited by: Donald, J. and Rattanzi, A. (red.), London, Sage, 1992.

Honneth, A.: The Struggle for Recognition: The Moral Grammar of Social Conflicts, Cambridge, Polity Press, 1995.

Jenkins, R.: Social Identity, London, Routledge, 1996.

Jenkins, R.: Categorization: Identity, Social Process and Epistemology, Curr. Sociol., 48, 7-25, 2000.

Koefoed, L. and Simonsen, K.: The Price of Goodness. Everyday Nationalist Narratives in Denmark, Antipode, 39, 310-330, 2007.

Koefoed, L. and Simonsen, K.: Den "fremmede", byen og nationen, Frederiksberg, Roskilde Universitetsforlag, 2010.

Lakoff, G. and Johnson, M.: Hverdagens metaforer, København, Hans Reitzels Forlag, 2002.

Quraishi, B.: Det pakistanske samfund i Danmark. Fra Punjab til Vesterbro, Frederiksberg, Forlaget Etnisk Debatforum, 1999.

Schuetz, A.: The Stranger: An Essay in Social Psychology, Am. J. Sociol., 49, 499-507, 1944.

Simmel, G.: The stranger, in: The Sociology of Georg Simmel, edited by: Wolff, K. (trans), New York, Free Press, 402-408, 1950 [1908].

Werbner, P.: Imagined Diasporas among Manchester Muslims. The Public Performance of Pakistani Transnational Identity Politics, Oxford: James Currey and Santa Fe, School of American Press, 2002,

Zizek, S.: Tarrying with the negative: Kant, Hegel and the critique of ideology, Durham, Duke University Press, 1993.

Zizek, S.: Violence: six sideways reflections, New York, Picador, 2008. 